日臨外医会誌 $54(10) ， 2486-2489 ， 1993$

原

著

\title{
乳癌組織における p53蛋白発現の臨床病理学的検討
}

\author{
名古屋大学第 2 外科（主任：高木 弘教授） \\ 成田達彦舟橋啓臣佐藤康幸高木弘
}

乳癌における 553 蛋白の発現を免疫組織学的に検討した。ポリクローナル抗体を用い たホルマリン固定ハララフィン包埋標本における検討では，p53蛋白の発現は179例中49例 (27.4\%) の癌細胞核に限局して認められた。 p53蛋白の組織発現と臨床病理学的背景因 子，PCNA labeling index および予後との有意の相関は認められなかった．以上より乳 癌組織では変異型 p53蛋白の発現がみられ，p53遺伝子の癌化における関与が示唆された がそこの臨床的意義に関してはさらに検討を要すると考えられた。

索引用語：乳癌, p53蛋白, 免废組儎染色

はじめに

17 番染色体短腕上に存在する $\mathrm{p} 53$ 遭层子は正常細胞 では癌抑制遗层子として機能している゙。しかし, 癌細 胞においてはp53遺云子の変異が高率に認めら $れ^{21-5)}$, 乳癌に拈いては変異型 $\mathrm{p} 53$ 蛋白の組織発現と悪 性度との関連を指摘する報告むある(1)-9!. 今回, 乳癌組 轹における p53蛋白の発現と, その臨床的意義を検討 するために，免度組織化学的方法を中心とした臨床病 理学的検討を行った

\section{対象と方法}

1979年より1991年むでに当教室ならびに関連施設で 手術が行われた浸潤性乳管癌症例を検討対象とした。 全例女性で，平均観察期間は49力月であった。

230例の原発巣切除標本のホルマリン固定バラフィ ン包埋標本より $3 \mu \mathrm{M}$ の切片を作成し， $\mathrm{ABC} キ ッ 卜$ (Vector Lab. Inc., Burlingame, CA) を用いた avidin-biotin peroxidase complex 法 (ABC 法) によ る免疫組織染色を行った。1 次抗体としては，ます抗 Proliferating Cell Nuclear Antigen (PCNA) モノク ロ一ナル抗体, TOB7 ${ }^{10)}$ (順天堂大学内科 高崎芳成博 士より恵与)を用い，切片標本上にPCNA の陽性所見 が認められた179例を対象として抗 $\mathrm{p} 53$ 蛋白ボリクロ ナール抗体，CM-1 (Novocastra Lab. Ltd., Newcastle，UK $)^{11}$ を用いて同様に免疫組織染色を行った.

免度組織染色上の p53蛋白の発現の判定は，(H)： 切片標本全体の細胞核が陽性所見を示するの，(十)： 一部分の細胞核が陽性所見を示すむの，(）：全く陽

1992 年10月 17 日受付 1993 年 3 月19日採用
性細胞が認められないものとした。 またPCNAの発 現の判定は切片上の最も強く染色された部位を選び， 光顕的に強扗大で200個以上の細胞核を数えこれを 5 視野について行い，平均化して陽性細胞率（\%）を Labeling. Index（LI）とした. p53蛋白の組織発現と 臨床病理学的背景因子との相関の解析には $x^{2}$ 検定を， 予後との相関の解析には Kaplan-Meier 法を用い，標 準化 Wilcoxon 検定を行った。

\section{結 果}

p53蛋白の発現は，179例中49例（27.4\%）の癌細胞 核に認められた。発現様式には 2 種類あり，ほぼ全て の細胞核が陽性所見を示すむのと，一部分の細胞核の みが陽性所見を示す場合が認められた。癌に隣接する 非癌部乳管上皮では全く発現は認められなかった（図 1). p53蛋白の発現と臨床病理学的背景因子には有意 の相関は認められなかった（表 1 ）。病期IVを除く164 例を対象に予後との相関を解析すると，p53蛋白陽性 例は陰性例に比して予後不良の傾向が認められたが， その盖は有意ではなかった（図 2).p53蛋白の発現と disease free interval および初発再発・転移部位之の 間には相関は認められなかった（表 2 )。ささらに p53蛋 白の発現とPCNA LI との相関る認められなかった (表 3 ).

\section{考 案}

乳癌では17番染色体短腕の欠失が高率に認めら $れ^{21212)}$,この部にある $\mathrm{p} 53$ 遺厷子は癌抑制遭伝子として 機能しているとされる゙．しかし，変異型 $\mathrm{p} 53$ 遺层子は 逆に癌化を促進する作用を有することが示唆されてい る3).今回用いたポリクローナル抗体は，野性型む变異 

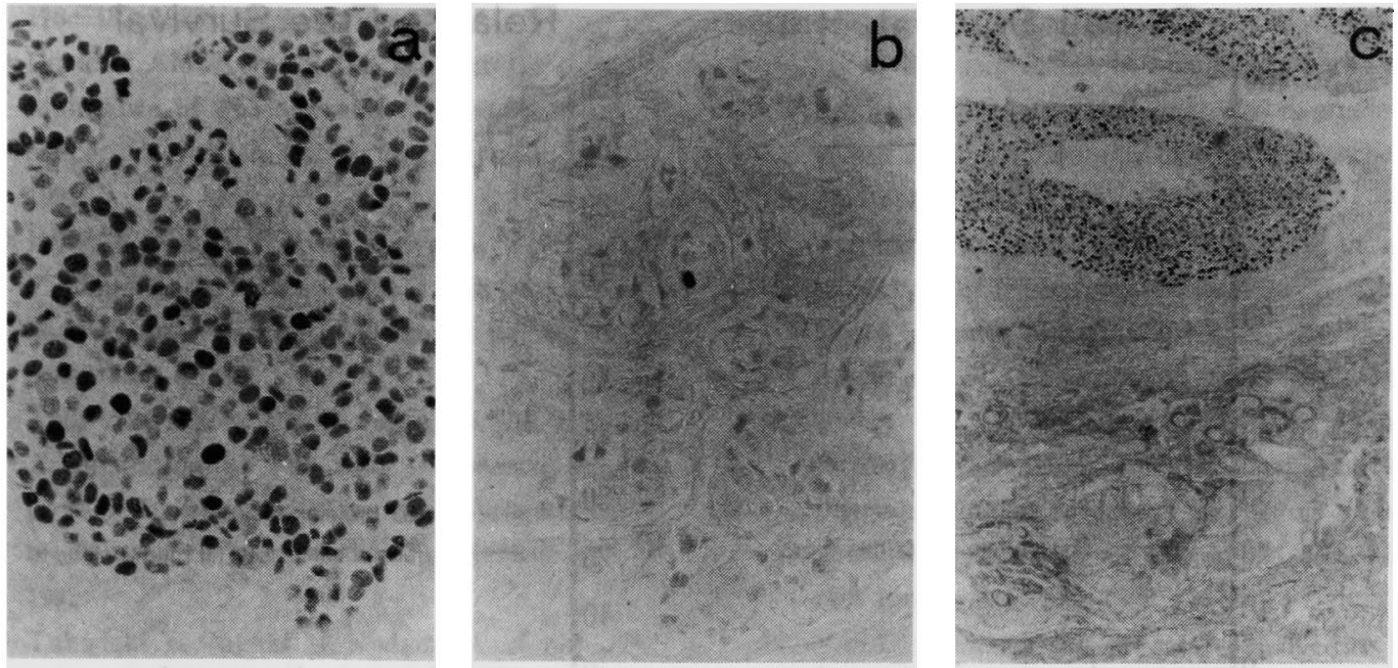

図 1 乳病組織における p53蛋白の発現(ABC 法)：a）ほぼ全ての癌細胞核が陽性 $(\times 400), b)$ 一 部の細胞核のみが陽性 $(\times 400) ， c ）$ 癌部にのみ陽性所見を認める $(\times 100)$.

表 $1 p 53$ 蛋白の発現と臨床病理学的背量因子の相間

\begin{tabular}{|c|c|c|c|c|c|}
\hline & \multirow{2}{*}{$\mathrm{n}$} & \multicolumn{3}{|c|}{ p53蛋白 } & \multirow{2}{*}{$\mathrm{p}$} \\
\hline & & $(-)$ & $(+)$ & $(H)$ & \\
\hline \multicolumn{6}{|l|}{ 手術時年報 } \\
\hline$<50$ 瓷 & 81 & 58 & 7 & 16 & NS \\
\hline$\geqq 50$ 紫 & 98 & 71 & 8 & 19 & \\
\hline \multicolumn{6}{|l|}{ 腫舫径 } \\
\hline$<2 \mathrm{~cm}$ & 67 & 48 & 8 & 11 & \\
\hline $2-5 \mathrm{~cm}$ & 78 & 57 & 7 & 14 & NS \\
\hline$>5 \mathrm{~cm}$ & 34 & 25 & 0 & 9 & \\
\hline \multicolumn{6}{|l|}{ リンバ節転移 } \\
\hline なし & 107 & 82 & 9 & 16 & \\
\hline 1-3個 & 31 & 22 & 3 & 6 & NS \\
\hline$\geqq 4$ 個 & 41 & 26 & 3 & 12 & \\
\hline \multicolumn{6}{|l|}{ TNM 病期 } \\
\hline I 期 & 60 & 43 & 8 & 9 & \\
\hline II 期 & 78 & 57 & 6 & 15 & NS \\
\hline III 期 & 26 & 19 & 1 & 6 & \\
\hline N 期 & 15 & 11 & 0 & 4 & \\
\hline \multicolumn{6}{|l|}{ 病理組悢型 } \\
\hline 硬癌 & 42 & 31 & 5 & 6 & \\
\hline 充実腺管癌 & 93 & 61 & 8 & 24 & NS \\
\hline 乳頭腺管癌 & 43 & 37 & 2 & 4 & \\
\hline 粘液癌 & 1 & 1 & 0 & 0 & \\
\hline エストロゲンレセブター & & & & & \\
\hline 陰性 & 27 & 15 & 2 & 10 & \\
\hline 陽性 & 48 & 37 & 4 & 7 & NS \\
\hline 不明 & 104 & 78 & 9 & 17 & \\
\hline Total & 179 & 130 & 15 & 34 & \\
\hline
\end{tabular}

NS : not significant
表 2 53蛋白の発現と再発様式

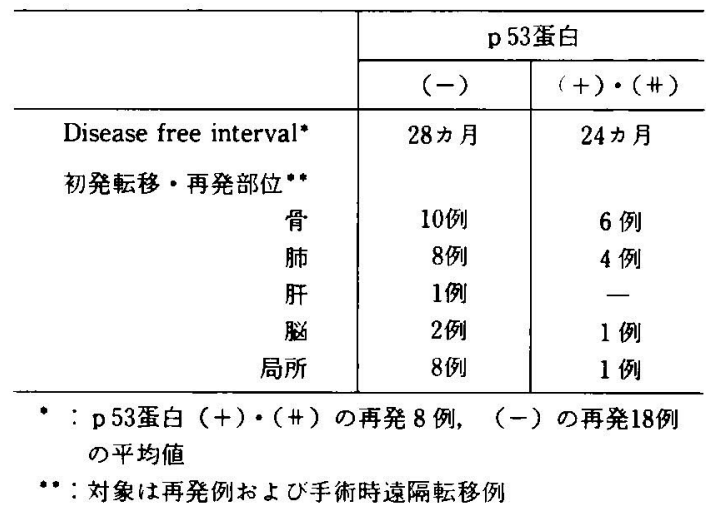

表 3 p 53蛋白の発現と PCNA labeling index (LI) との相関

\begin{tabular}{rr|r|r}
\hline & & $\mathbf{n}$ & $\begin{array}{c}\text { PCNA LI } \\
(\text { Mean } \pm \text { SD) }\end{array}$ \\
\hline & $(-)$ & 130 & $29.3 \pm 27.0$ \\
p 53蛋白 & $(+)$ & 15 & $33.5 \pm 30.0$ \\
& $(+)$ & 34 & $34.6 \pm 29.5$ \\
\hline
\end{tabular}

型も認識するものだが，変異型は野性型よりも安定て 細胞核に蓄積しやすいとされ13)，さらに本抗体により 認識される $\mathrm{p} 53$ 蛋白の発現は癌部においての䚺めら れたことからも，今回免疫組織化学的に発現か認めら れた p53蛋白は変異型と考えられた。 


\section{Overall Survival}

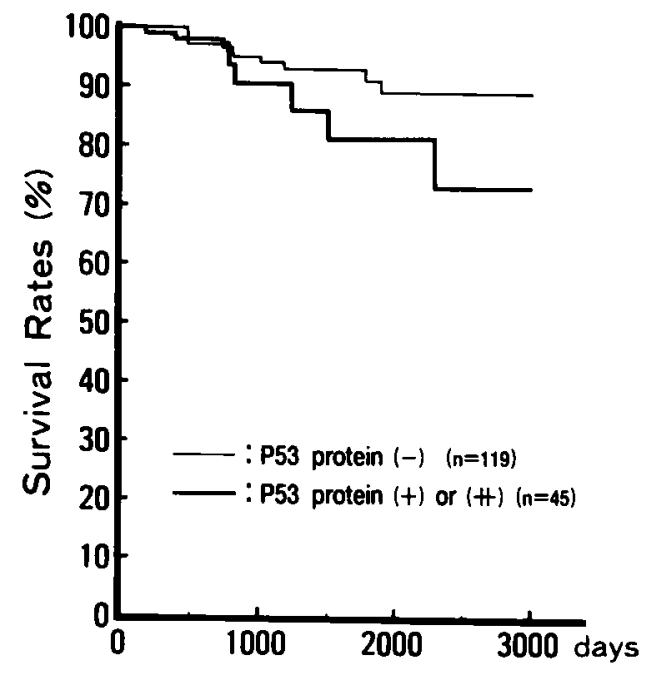

\section{Relapse Free Survival}

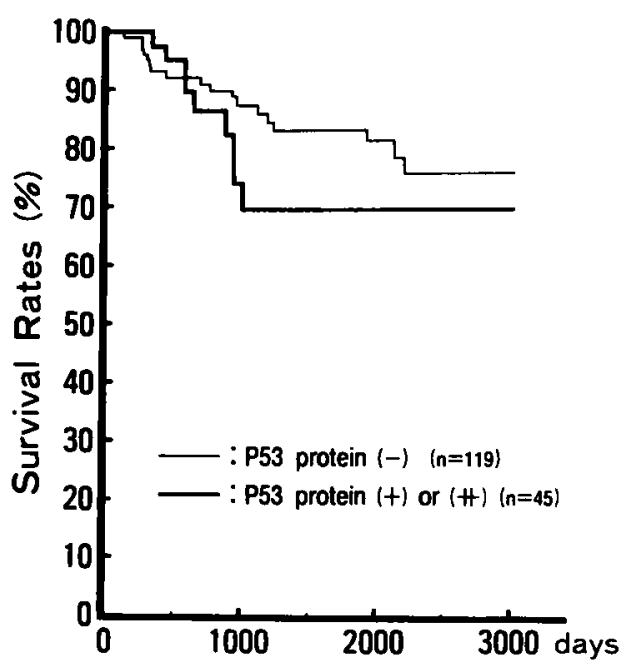

图 2 p53蛋白の組維発現と予後

p53蛋白のような核蛋白質の発現を通常のホルマリ ン固定パラフィン包埋標本を用いて検討する場合に問 題となるのは，固定などによる抗原性の失活に伴ら偽 陰性を考磨する必要があることである。このため，今 回はp53蛋白発現の検討に先立ち，同じ核蛋白質であ るPCNAの発現を検討し, PCNAの発現が全く認め られなかったるのは検討から除外した. 今回の検討に おける 553 蛋白の陽性率は27.4\%であったが，これは 新鮮凍結標本を用いた場合の陽性率6) 8)とほぼ一致 し，通常のホルマリン固定ハララフィン包埋標本を用い ても, p53蛋白の免疫組織化学的な検討は充分に可能 と考えられた。

p53蛋白の組織発現の臨床的意義に関する検討は充

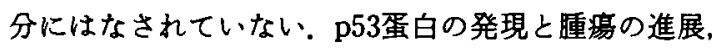
組織学的悪性度, 紐胞増殖能, エストロゲンレセブター の有無, epidermal growth factor receptor, c-erbB2蛋白の発現などとの相関を指摘し,p53蛋白の発現は 悪性度の指標となりらるとする報告す散見され る(6) 8). しかし, 今回の検討に扎いては p53蛋白の発現 と臨床病理学的背景因子や細胞増殖能の指標之され る14PCNA LI との相関は認められなかった。 また予 後との間にる有意の相関は認められなかった，以上よ り，乳癌における p53蛋白の発現の悪性度の指標およ び予後因子としての意義は明らかではなく，その臨床 的意義に関してはさらに検討を要すると考えられた。

\section{結語}

乳癌組織における 553 蛋白の発現を免疫組織化学的 に検討した. $\mathrm{p} 53$ 蛋白の発現率は $27.4 \%$ あっった. 今回 の検討においては，p53蛋白の組䢂発現と臨床病理学 的背景因子, PCNA labeling index 括よび予後との有 意の相関は認められず，その臨床的意義に関してはさ らに検討を要すると考えられた。

\section{References}

1) Levine AJ, Momand J, Finlay CA: The P53 tumour suppressor gene. Nature $351: 453-456$, 1991

2) Varley JM, Brrammar WJ, Lane DP, et al: Loss of chromosome $17 \mathrm{p} 13$ sequences and mutation of P53 in human breast carcinomas. Oncogene 6: 413-421, 1991

3) Nigro JM, Baker SJ, Preisnger $A C$, et al: Mutation in the P53 gene occur in diverse human tumor types. Nature $342: 705-708,1989$

4) Osborne RJ, Merlo GR, Mitsudomi T, et al : Mutations in the P53 gene in primary human breast cancer. Cancer Res 51 : 6194-6198, 1991

5) Bartek J, Iggo R, Cannon J, et al : Genetic and immunohistochemical analysis of mutaznt P53 in human breast cancer cell lines. Oncogene 5 : 893-899, 1990

6) Cattoretti G, Rilke F, Andreola S, et al: P53 expression in breast cancer. Int $\mathrm{J}$ Cancer 41 : 


$$
178-183,1988
$$

7) Davidoff AM, Kerns B-JM, Iglehart JD, et al : Maintance of P53 alterations throught breast cancer progression. Cancer Res 51 : 2605-2610, 1991

8) Iwaya $K$, Tsuda $H$, Hiraide $H$, et al : Nuclear P53 immunoreaction associated with poor prog. nosis of breast cancer. Jpn J Cancer Res 82 : 835 $-840,1991$

9) Thor AD, Moore DH II, Edgerton SM, et al : Accumulation of P53 tujor suppressor gene protein : An independent marker of prognosis in breast cancers. J Natl Cancer Inst 84 : 845-855, 1992

10) Takasaki Y, Ohgaki M, Kodama A, et al: A sandwich type enzymelinked immunosorbent assay for proliferating cell nuclear antigen (PCNA)/cyclin using monoclonal antibodies. J Immunol Methods 132 : 227-237, 1990
11) Midgley CA, Fisher CJ, Bartek J, et al : Analysis of P53 expression in human tumours: An antibody raised against human P53 expressedy raised against human $\mathrm{P} 53$ expressed in escherichia coli. J Cell Sci $101:$ 183-189, 1992

12) Sato $T$, Tanigami A, Yamakawa $K$, et al : Allelotype of breast cancer : Cumulative allele losses promote tumor progression in primary breast cancer. Cancer Res $50: 7184-7189,1990$

13) Finlay CA, Hinds PW, Tan $T H$, et al: Activating mutations for transformation by P53 produce a gene probuct that forms an hsc 70-P53 complex with an altered half-life. Mol Cell Biol 8: 531-539, 1988

14) Van Dierendonck JH, Wijsman JH, Keijzer R, et al: Cell-cycle-related staining pattern of anti-proliferating cell nuclear antigen monoclonal antibodies. Am J Pathol 138 : 1165-1172, 1991

\section{CLINICOPATHOLOGICAL STUDY OF p53 PROTEIN EXPRESSION IN BREAST CANCER TISSUE}

\section{Tatsuhiko NARITA, Hiroomi FUNAHASHI, Yasuyuki SATOH and Hiroshi TAKAGI Department of Surgery II, Nagoya University School of Medicine}

The authors have conducted an immunohistochemical study of the expression of p53 protein in breast cancers. This study based on formalin fixed paraffin embedded specimens using a polyclonal antibody showed that the expression of p53 protein was observed limited to the nuclei of cancer cells in 49 out of 179 cases (27.4\%). No significant correlations were observed between the tissue expression of the p53 protein and clinicopathological background factors, PCNA labeling index, and prognosis. Given the above, the expression of mutant-type p53 protein was observed in the breast cancer tissue, and possible involvement of the p53 gene in carcinogenesis was suggested. However, its clinical significance remains unknown and further investigations would be necessary. 